\title{
Assessment of Cadmium and Lead in Dried Sewage Sludge from Lubigi Feacal Sludge and Wastewater Treatment Plant in Uganda
}

\author{
Juliet Kyayesimira ${ }^{*}$, Abbey Ssemaganda², Godfrey Muhwezi ${ }^{3}$, Morgan Andama ${ }^{4}$ \\ ${ }^{1}$ Department of Biology, Kyambogo University, Kampala, Uganda \\ ${ }^{2}$ Uganda Virus Research Institute, Entebbe, Uganda \\ ${ }^{3}$ Department of Chemistry, Muni University, Arua, Uganda \\ ${ }^{4}$ Department of Biology, Muni University, Arua, Uganda \\ Email: *kyayejue@gmail.com
}

How to cite this paper: Kyayesimira, J., Ssemaganda, A., Muhwezi, G. and Andama, M. (2019) Assessment of Cadmium and Lead in Dried Sewage Sludge from Lubigi Feacal Sludge and Wastewater Treatment Plant in Uganda. Journal of Water Resource and Protection, 11, 690-699.

https://doi.org/10.4236/jwarp.2019.116040

Received: April 3, 2019

Accepted: June 7, 2019

Published: June 10, 2019

Copyright $\odot 2019$ by author(s) and Scientific Research Publishing Inc. This work is licensed under the Creative Commons Attribution International License (CC BY 4.0).

http://creativecommons.org/licenses/by/4.0/

\begin{abstract}
Sludge contains organic and inorganic compounds including traces of heavy metals such as lead $(\mathrm{Pb})$, cadmium $(\mathrm{Cd})$, copper $(\mathrm{Cu})$, nickel $(\mathrm{Ni})$, chromium $(\mathrm{Cr})$ and others. These metals restrict the use of sludge in agriculture because their accumulation is harmful to the environment and particularly the food chain. Cadmium and lead are among the most common heavy metals found in municipal wastewater treatment plant sludge. They are capable of bioaccumulation in plant tissues like roots and leaves and are non-biodegradable and therefore they remain in the sludge which is disposed on land or used as fertilizers on farms. The presence of heavy metal pollutants serves as a great threat to soils and also makes plants grown on such soils unfit for animal and human consumption as they may have detrimental effects to animal and human life. For instance, $\mathrm{Pb}$ and $\mathrm{Cd}$ are known to be human carcinogens. This study therefore aimed to investigate the levels of $\mathrm{Cd}$ and $\mathrm{Pb}$ in the treated dry sludge from Lubigi Feacal Sludge and Wastewater treatment plant located in Kawempe division, Kampala city, Uganda so as to ascertain its safety for use on agricultural lands. Two batches of samples were collected and analyzed at Government Analytical laboratory in Wandegeya, Uganda. The acid digested sludge samples were analyzed using Atomic Absorption Spectroscopy (AAS) method. The average concentrations of $\mathrm{Pb}$ found in collected sludge samples, batch $1(11.912 \mathrm{mg} / \mathrm{kg} \mathrm{dm})$ and batch $2(5.304 \mathrm{mg} / \mathrm{kg} \mathrm{dm})$ were far below the Environment Protection Agency (EPA) maximum permissible concentration $(840 \mathrm{mg} / \mathrm{kg})$ for any land application. Cadmium was not detected in all the sludge samples collected; there is an implication that it is either completely absent in the sludge generated by the plant or present but far below detectable
\end{abstract}


levels. The sludge generated from Lubigi fecal sludge and wastewater treatment plant is therefore safe for application on agricultural lands as far as $\mathrm{Pb}$ and Cd concentrations are concerned.

\section{Keywords}

Lead, Cadmium, Sludge, Wastewater, Treatment, Uganda

\section{Introduction}

The Lubigi Feacal Sludge and Wastewater Treatment Plant in Kampala, Uganda was commissioned in May 2014 and has a capacity to treat $400 \mathrm{~m}^{3}$ of feacal sludge and $5000 \mathrm{~m}^{3}$ of wastewater per day [1] [2]. Faecal sludge (FS) comes from onsite sanitation technologies (pit latrines, unsewered public ablution blocks, septic tanks, aqua privies, and dry toilets) and has not been transported through a sewer. It is raw or partially digested, a slurry or semisolid, and results from the collection, storage or treatment of combinations of excreta [3].

Sewage sludge is waste coming from municipal wastewater treatment plants and it contains at least $80 \%$ of water and nutrient-rich organic materials, inorganic compounds, including traces of non-biodegradable heavy metals such as lead $(\mathrm{Pb})$, silver $(\mathrm{Ag})$, cadmium $(\mathrm{Cd})$ and others [4]. Hence the sludge has a high potential to be used for fertilization of gardens [4]. However, if the sewage sludge has heavy metals in concentrations higher than the permissible limits, it is not suitable for reuse in gardens and other activities as it is hazardous to the environment [5]. This is because the soluble heavy metal ions bioaccumulate in organisms through food chain posing harmful health threats to the organisms and the environment [6] [7]. For instance, leafy and non-leafy vegetables of food plants are good accumulators of heavy metals and the bioaccumulation pattern in non-leafy vegetables increases in the order; leaf $>$ root $=$ stem $>$ tuber. These heavy metals end up in human beings and animals who consume the vegetables. Heavy metals are also known to have strong influence on nutritional values of plants. Plants grown on metal-contaminated soils are nutrient deficient and consumption of such vegetables may lead to nutritional deficiency in the population [8].

Lubigi feacal sludge and wastewater treatment receive feacal sludge from toilets and latrines in Kampala city. The plant handles wastewater from Mulago hospital, Makerere University and other different locations around Kampala city with many business activities including education institutions, laboratories, garages, workshops and markets. These activities may be an important source of $\mathrm{Pb}$ and $\mathrm{Cd}$ contamination through storm runoff especially of electronic wastes from electronic workshops, corrosion of old buildings painted with $\mathrm{Pb}$ containing paints, and battery (Lead acid batteries) wastes from battery workshops around town including hospital wastes. However, treated and dried sludge from Lubigi feacal sludge and wastewater treatment plant is used as organic fertilizer 
by some farmers for enriching agricultural soils with nutrients especially nitrogen and phosphorus [9]. Much as previous studies of feacal sludge at Lubigi sewage treatment plant showed reduced detectable levels of $E$. coli, bacteriophages and Ascaris eggs throughout the time of storage when treated with urea and lime [10], there is limited monitoring of the levels of heavy metals in sludge from the treatment plant before being used as fertilizer. Therefore, this study assessed the levels of $\mathrm{Cd}$ and $\mathrm{Pb}$ metals in the treated dried sewage sludge generated by the Lubigi feacal sludge and wastewater treatment plant.

\section{Materials and Methods}

\subsection{Study Area}

The study was carried out on the Lubigi feacal sludge and wastewater treatment plant (GPS; N0.33998 ; E32.56032 ${ }^{\circ}$ ). It is located on Lubigi wetland in Kawempe division, Kampala district along the northern bypass Hoima road about $5 \mathrm{~km}$ from Kampala city square in Uganda (Figure 1). Lubigi wetland has had most of the natural vegetation cleared due to anthropogenic activities especially in the northern part of the wetland. The socio-economic activities around the treatment plant include agriculture, road construction, settlements and collection of fodder and building materials for sale [11]. Lubigi waste-water and Sewage Treatment Plant serves Kawempe, Bwaise, Katanga, Makerere, Nsooba and includes hotspots like Mulago Hospital, Public Service and Wandegeya areas and all these have many business activities. Lubigi plant is the second treatment plant in Kampala [9]. The plant receives and treats wastewater from the piped network and feacal sludge brought by private cesspool emptier trucks [11].

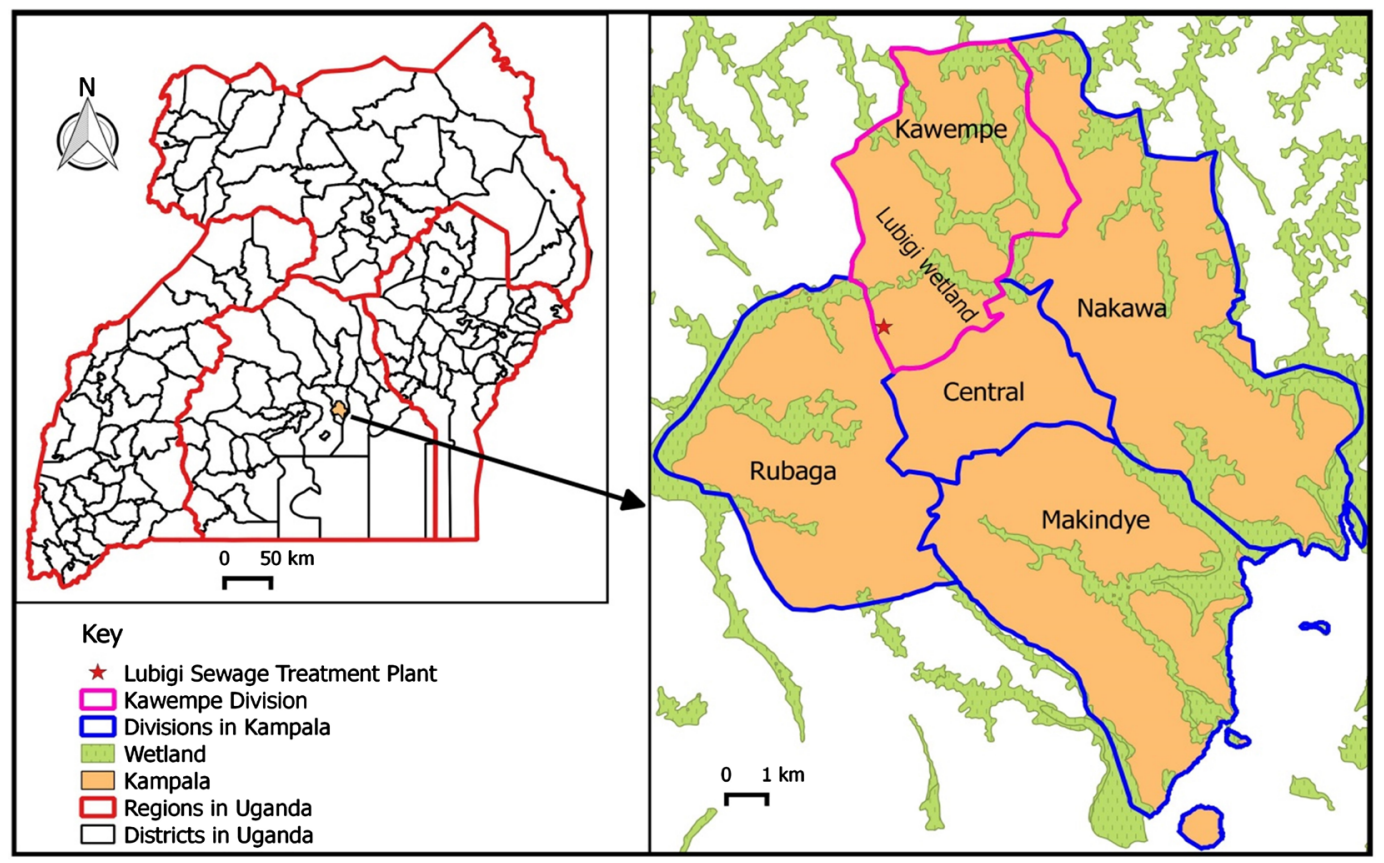

Figure 1. Map showing location of Lubigi fecal sludge and wastewater treatment plant. Source: Generated from QGIS 3.2. 


\subsection{Sample Sites and Sample Collection}

With the formal permission from the research management of both National Water and Sewerage Corporation and Lubigi feacal sludge and wastewater treatment plant, sludge samples were randomly collected from different drying beds of the plant in June 2017. Gloved hands were used to pick the sludge samples from the beds and these were put in clean, sterile plastic containers, labeled and then placed in a cool box with ice. After transport, the samples were placed in a refrigerator at $4^{\circ} \mathrm{C}$ awaiting further analysis.

Two batches of sludge samples were collected with a time interval of two weeks between the collection of the first batch and second. Two batches of samples were collected to ensure that two different sludge collections at the plant are tested to check for the continuity of the presence of these metals in the sludge generated by the plant. Each batch comprised of 10 samples making a total number of 20 samples.

\subsection{Preparation of the Aqua Regia}

The aqua regia is a mixture of $\mathrm{HCl}$ and $\mathrm{HNO}_{3}$ [12] [13] in a ratio of 3:1 respectively [14]. A volume of $250 \mathrm{ml}$ of the aqua regia was prepared for each batch of samples following a standard method [15]. An amount of $187.5 \mathrm{ml}$ of $37 \% \mathrm{HCl}$ was put in a clean $1000 \mathrm{ml}$ measuring cylinder and $62.5 \mathrm{ml}$ of $65 \% \mathrm{HNO}_{3}$ was added to the same measuring cylinder to form a mixture. Freshly prepared aqua regia was used for each batch of samples.

\subsection{Preparation of Samples}

The samples were prepared according to the method of [12] and [15]. The samples were subjected to acid digestion using the aqua regia. A mass of $1.250 \mathrm{~g}$ of each sample was ground, air dried, and transferred to a respectively labelled destruction tube (digestion tube). The tubes were placed on a digestion block. Distilled water $(50 \mathrm{ml})$ was then added to each sample in the digestion tube followed by $50 \mathrm{ml}$ of the aqua regia. The digestion block was later switched on and the tubes heated to $100^{\circ} \mathrm{C}$ for 1 hour. The heating temperature was increased to $125^{\circ} \mathrm{C}$ and heated for 15 minutes followed by $150^{\circ} \mathrm{C}$ for 15 minutes and $175^{\circ} \mathrm{C}$ for 15 minutes. The heating temperature was further increased to $200^{\circ} \mathrm{C}$ and heated until there was no volume of the mixture left, then $5 \mathrm{ml}$ of $65 \% \mathrm{HNO}_{3}$ was added. The solution in the tubes was then concentrated to about $5 \mathrm{ml}$. After cooling, $1 \mathrm{ml}$ of $30 \% \mathrm{H}_{2} \mathrm{O}_{2}$ solution was added and the mixture destructed for 10 minutes. After cooling, $3 \mathrm{ml}$ of $30 \% \mathrm{H}_{2} \mathrm{O}_{2}$ solution was added and the mixture destructed again for another 10 minutes. Distilled water $(50 \mathrm{ml})$ and $25 \mathrm{ml}$ of $37 \% \mathrm{HCl}$ were then added and the mixture heated till boiling. The samples were then cooled and filtered into $50 \mathrm{ml}$ volumetric flasks, made up to the mark with $1 \% \mathrm{HNO}_{3}$, and transferred into $50 \mathrm{ml}$ falcon tubes. The samples were then allowed to settle for at least 15 hours. The absorbance of the clear supernatant was then measured using an Atomic Absorption Spectrophotometer (AAS). For each run of 
samples, a blank sample was added and treated the same way as the samples.

\subsection{Preparation of Standards}

Standard solutions of $\mathrm{Pb}(10 \mathrm{ml})$ and $\mathrm{Cd}(10 \mathrm{ml})$ were each pipetted into separate $1000 \mathrm{ml}$ volumetric flasks and $20 \mathrm{ml}$ of nitric acid added. Distilled water was then added up to the mark. The solutions were mixed thoroughly and stored for use.

\subsection{Metal Analysis by Atomic Absorption Spectrophotometer (AA-6300)}

Similar studies have used this method in quantification of trace elements in the sludge, food, soil and water [16] [17] [18] [19] [20]. Samples were aspirated by the instrument into a burner, desolvated, atomized, and excited to a higher energy electronic state. The use of a flame during analysis required fuel and oxidant, typically in the form of gases. The gas acetylene was the flame used and a hollow cathode lamp of the corresponding element was the resonance. The use of special light sources and careful selection of wavelength allowed the specific quantitative determination of individual elements in the presence of others. Light detectors in the instrument detect light with the analysis information coming from the flame. The information is amplified by a photomultiplier and displayed on the computer. The instrument was designed in such a way that it analyses each sample in triplicate and then computes the average concentration of the metals in each sample. The AA-6300 reported the trace element concentrations in milligrams per kilogram.

\subsection{Data Analysis}

Microsoft excel version 2011 was used to calculate the descriptive statistics (minimum, maximum, mean, standard deviation) of the concentrations of $\mathrm{Pb}$ and $\mathrm{Cd}$ in the sludge. The descriptive statistics and the raw values of $\mathrm{Pb}$ and $\mathrm{Cd}$ in the two sample batches of the sludge are presented in Table 1. Comparison of the mean concentrations of $\mathrm{Pb}$ and $\mathrm{Cd}$ in batch 1 and batch 2 samples was done using computer software IBM SPSS Version 20 (IBM Corp. Armonk, NY: Released 2011) for independent samples t-test at $5 \%$ level of significance and the results also summarized in Table 1 .

\section{Results and Discussion}

\section{Concentration of $\mathrm{Pb}$ and $\mathrm{Cd}$ in Sludge from Lubigi Sludge Treatment Plant}

The results from the batch 1 of samples collected from Lubigi sludge treatment plant showed presence of $\mathrm{Pb}$ but $\mathrm{Cd}$ was absent (Table 1). The concentration of $\mathrm{Pb}$ in the sludge of batch 1 samples ranged from 4.10 to $20.87 \mathrm{mg} / \mathrm{kg}$ dry mass with a mean value of $11.80 \pm 6.30 \mathrm{mg} / \mathrm{kg}$ (Table 1 ).

Batch 2 samples were collected after 2 weeks interval to monitor if there was any change in the concentration of heavy metals in the sludge. The amount of $\mathrm{Pb}$ 
Table 1. Concentration (mg/kg dry mass) of $\mathrm{Pb}$ and $\mathrm{Cd}$ in sludge from Lubigi sludge treatment plant and the EPA maximum permissible limit.

\begin{tabular}{|c|c|c|c|c|c|c|c|c|}
\hline \multicolumn{3}{|c|}{ Batch 1} & \multicolumn{3}{|c|}{ Batch 2} & \multicolumn{3}{|c|}{$\mathrm{t}$ test } \\
\hline Batch No. & $\mathrm{Pb}$ & $\mathrm{Cd}$ & Batch No. & $\mathrm{Pb}$ & $\mathrm{Cd}$ & $\mathrm{t}$ & $\mathrm{df}$ & $\mathrm{p}$ \\
\hline Lbg1 & 4.10 & 0 & $\operatorname{Lbg} 11$ & 0.93 & 0 & & & \\
\hline Lbg2 & 7.85 & 0 & $\operatorname{Lbg} 12$ & 4.14 & 0 & & & \\
\hline Lbg3 & 14.84 & 0 & $\operatorname{Lbg} 13$ & 6.28 & 0 & & & \\
\hline $\operatorname{Lbg} 4$ & 20.87 & 0 & Lbg14 & 9.18 & 0 & & & \\
\hline $\operatorname{Lbg} 5$ & 7.85 & 0 & $\operatorname{Lbg} 15$ & 4.23 & 0 & & & \\
\hline Lbg6 & 14.84 & 0 & $\operatorname{Lbg} 16$ & 6.00 & 0 & & & \\
\hline Lbg7 & 20.87 & 0 & Lbg17 & 6.28 & 0 & & & \\
\hline Lbg8 & 14.84 & 0 & $\operatorname{Lbg} 18$ & 9.06 & 0 & & & \\
\hline Lbg9 & 4.10 & 0 & $\operatorname{Lbg} 19$ & 0.93 & 0 & & & \\
\hline $\operatorname{Lbg} 10$ & 7.85 & 0 & Lbg20 & 6.01 & 0 & & & \\
\hline Min. & 4.10 & 0 & Min. & 0.93 & 0 & & & \\
\hline Max. & 20.87 & 0 & Max. & 9.18 & 0 & & & \\
\hline Mean \pm SD & $11.80 \pm 6.30$ & 0 & Mean \pm SD & $5.30 \pm 2.84$ & 0 & 2.971 & 18 & 0.008 \\
\hline EPA & 840 & 85 & EPA & 840 & 85 & & & \\
\hline
\end{tabular}

Key: Lbg: Lubigi, SD: Standard Deviation, EPA: Environmental Protection Agency, mg: Milligram, Kg: Kilogram, No: Number, df: Degree of Freedom, Min.: Minimum, Max.: Maximum

in batch 2 samples ranged from 0.93 to $9.18 \mathrm{mg} / \mathrm{kg}$ dry mass with a mean concentration of $5.30 \pm 2.84 \mathrm{mg} / \mathrm{kg}$. The mean concentration of $\mathrm{Pb}$ in Batch 1 samples was significantly $(\mathrm{p}<0.05)$ higher than that of batch 2 samples. Just like batch 1, Cd was also not detected in all the batch 2 samples. The lower levels of $\mathrm{Pb}$ in batch 2 than batch 1 is probably caused by the incoming wastewater that is less contaminated.

The mean concentration of $\mathrm{Pb}$ in the Lubigi sludge for both batch 1 and batch 2 samples were far below the EPA maximum permissible limit of $840 \mathrm{mg} / \mathrm{kg}$ [21] for any land application as shown in Table 1 . The lower mean concentration of $\mathrm{Pb}$ than the EPA limit and the undetectable levels of $\mathrm{Cd}$ in Lubigi sludge are contrary to the findings from waste stabilization ponds in Dar es salaam, Tanzania where the concentrations of the heavy metals in the sludge were higher than permissible limits [5]. Hence the sludge from Lubigi pond is suitable for disposal into soil or reuse in gardens.

Furthermore, the concentration of $\mathrm{Pb}$ in this study was in low amounts when compared with the study in the Eastern Cape province, South Africa where $\mathrm{Pb}$ levels were found to range from 69 to $365 \mathrm{mg} / \mathrm{kg}$ d.m for the sewage sludge from sewage treatment plants (STPs) [22]. In a study in Limpopo Province, South Africa, $\mathrm{Pb}$ concentrations in the sludge ranged from 21.3 to $171.85 \mathrm{mg} / \mathrm{kg} \mathrm{d} \cdot \mathrm{m}$ [23] but high $\mathrm{Pb}$ concentrations in excess of DWAF (Department of Water Affairs and Forestry) guideline values [24] were found in towns of Polokwane and 
Louis Trichardt which gives the maximum threshold of $\mathrm{Pb}$ at $100 \mathrm{mg} / \mathrm{kg} \mathrm{d} \cdot \mathrm{m}$.

It is important to note that though there was very low concentration of $\mathrm{Pb}$ in the Lubigi sludge, another study conducted in Kampala city found the $\mathrm{Pb}$ content in water samples from Lake Victoria and tap water ranged from 0.32 to 1.25 and 0.09 to $0.19 \mathrm{mg} / 100 \mathrm{ml}$, respectively. The $\mathrm{Pb}$ content in the vegetables grown alongside highways ranged from 0.53 to $0.95 \mathrm{mg} / 100 \mathrm{~g}$ [16] and this may come from other sources other than sludge.

It should be noted that the major source of $\mathrm{Pb}$ in the environment was probably the use of leaded petrol but since the year 2005, leaded petrol has been phased out from Sub Saharan Africa [25]. Therefore, the lower Pb concentrations in this study could be due to the phasing out of leaded petrol in Uganda. Lubigi fecal sludge and wastewater treatment plant are located close to high traffic roads from which $\mathrm{Pb}$ may enter from other sources for example from other industrial applications and anthropogenic activities.

Cadmium was not detected in all the samples and this means that it is either completely absent in the sludge or present but below detectable levels. Studies on the sewage sludge in the Eastern Cape province, South Africa found Cd levels in the ranges of 1.1 and $1.9 \mathrm{mg} / \mathrm{kg}$ [22] while another study found Cd amounts of $3.10 \mathrm{mg} / \mathrm{kg}$ d.m in municipal sewage sludge [23]. The major sources of Cd were probably the use of paints and plastics and application of rock phosphate fertilizers [26] and the heavy traffic roads city centres from which Cd may enter storm water drains that are connected to the sewage plant [23]. The absence or undetectable levels of $\mathrm{Cd}$ in this study could be due to the absence of Cd containing pigments/paints/batteries.

\section{Conclusion}

Lead concentrations in the sludge generated by the Lubigi fecal sludge and wastewater treatment plant showed significant variation in a short (2 weeks) sampling period possibly attributed to runoff of wastewater from various human activities in the city. These activities include electronic workshops, corrosion of old buildings painted with lead-containing paints, lead-acid batteries and hospital wastes among others. Nevertheless, the concentration of $\mathrm{Pb}$ in the sludge is low and far below the EPA maximum permissible concentration for any land application. On the other hand, $\mathrm{Cd}$ is either completely absent in the sludge from Lubigi sewage treatment plant or present but far below detectable concentrations. Therefore, sludge from the Lubigi treatment plant is safe for application on agricultural soils as far as $\mathrm{Pb}$ and $\mathrm{Cd}$ concentrations are concerned.

\section{Acknowledgements}

Special thanks go to the research manager National Water and Sewerage Corporation, Mr. Kanyesigye Christopher, and the manager Lubigi fecal sludge and wastewater treatment plant for granting permission to conduct this study at the plant. 
Great thanks go to Mr. Ssazi Job, Mr. Orwiny Martin of Lubigi fecal sludge and wastewater treatment plant for your assistance in sample collection and also unselfishly sharing with me your knowledge that tremendously helped streamline my study.

I am indebted to Ms. Solome Birungi and Mr. Sebulime Stephen of Government Analytical Laboratory and Mr. Eragu Richard of Natural chemotherapeutics laboratory. Without whose guidance I would not have come up with this piece of work. Thank you so much for the unreserved assistance in the laboratory analysis of my research samples.

I extend my gratitude to the Department of Biological Sciences of Kyambogo University for the support and guidance in the accomplishment of this work. May the almighty God reward all of you with abundance.

\section{Conflicts of Interest}

The authors declare no conflicts of interest regarding the publication of this paper.

\section{References}

[1] KCCA-KFSM (2017) Kampala Feacal Sludge Management; Improving Feacal Sludge Management for On-Site Sanitation. Kampala.

[2] Schoebitz, L., Bischoff, F., Lohri, C.R., Niwagaba, C.B., Siber, R. and Strande, L. (2017) GIS Analysis and Optimisation of Faecal Sludge Logistics at City-Wide Scale in Kampala, Uganda. Sustainability, 9, 194. https://doi.org/10.3390/su9020194

[3] Strande, L., Ronteltap, M. and Brdjanovic, D. (2014) Faecal Sludge Management; Systems Approach for Implementation and Operation. IWA Publishing, London. https://doi.org/10.26530/OAPEN_578132

[4] Lazdina, D., Lazdins, A., Bebre, I. and Gusarevs, I. (2017) Technological Process of Sewage Sludge De-Watering by Impulse Method and Assessment of Options to Use Dried Material. Engineering for Rural Development, 16, 217-221. https://doi.org/10.22616/ERDev2017.16.N041

[5] Mwakaboko, A.S., Lugwisha, E.H.J. and Kayogolo, C.W. (2014) The Performance of the Selected Waste Stabilization Ponds in Dar es salaam, Tanzania in Removing Heavy Metals. International Journal of Science, Environment and Technology, 3, 2024-2037.

[6] Bonfiglioli, C.S., Bianchini, L. and Pellegrini, M. (2014) Sewage Sludge: Characteristics and Recovery Options.

[7] Akpor, O.B., Ohiobor, G.O. and Olaolu, T.D. (2014) Heavy Metal Pollutants in Wastewater Effluents: Sources, Effects and Remediation. Advances in Bioscience and Bioengineering, 2, 37-43. https://doi.org/10.11648/j.abb.20140204.11

[8] Khan, A., Khan, S., Khan, M.A. and Qamar, Z. (2015) The Uptake and Bioaccumulation of Heavy Metals by Food Plants, Their Effects on Plants Nutrients, and Associated Health Risk: A Review. Environmental Science and Pollution Research, 22, 13772-13799. https://doi.org/10.1007/s11356-015-4881-0

[9] NWSC (2014) The Water Herald: Frontiers for Business Opportunities. Water Herald, Kampala, 1-36.

[10] Lindberg, E. and Rost, A. (2018) Treatment of Faecal Sludge from Pit Latrines and 
Septic Tanks Using Lime and Urea.

[11] Omagor, J. and Barasa, B. (2018) Effects of Human Wetland Encroachment on the Degradation of Lubigi Wetland System, Kampala City Uganda. Environment and Ecology Research, 6, 562-570. https://doi.org/10.13189/eer.2018.060606

[12] Christensen, T.H., Pedersen, L.R. and Tjell, J.C.H.R. (2007) Comparison of Four Methods for Digestion of Sewage Sludge Samples for Analysis of Metals by Atomic Absorption Spectrophotometry. International Journal of Environmental Analytical Chemistry, 12, 41-50. https://doi.org/10.1080/03067318208071569

[13] Urben, P. (2007) Bretherick's Handbook of Reactive Chemical Hazards. 7th Edition, Elsevier Ltd., Oxford.

[14] Bettinellia, M., Baffi, C., Beone, G. and Spezia, S. (2000) Soil and Sediment Analysis by Spectroscopic Techniques Part I: Determination of $\mathrm{Cd}, \mathrm{Co}, \mathrm{Cr}, \mathrm{Cu}, \mathrm{Mn}, \mathrm{Ni}, \mathrm{Pb}$, and Zn. Atomic Spectroscopy, 21, 37-76.

[15] Katz, S.A., Jenniss, S.W., Chatt, A., Tout, R.E. and Mount, T. (2007) Comparison of Sample Preparation Methods for the Determination of Metals in Sewage Sludges by Flame Atomic Absorption Spectrometry. International Journal of Environmental Analytical Chemistry, 9, 209-220. https://doi.org/10.1080/03067318108071515

[16] Mghweno, L.R., Makokha, A.O., Magoha, H.S. and Wekesa, J.M. (2008) Environmental Lead Pollution and Food Safety around Kampala City in Uganda. Journal of Applied Biosciences, 12, 642-649.

[17] Islam, R., Al Foisal, J., Rahman, M., Lisa, L.A. and Paul, D.K. (2016) Pollution Assessment and Heavy Metal Determination by AAS in Wastewater Collected from Kushtia Industrial Zone in Bangladesh. African Journal of Environmental Science and Technology, 10, 9-17. https://doi.org/10.5897/AJEST2014.1994

[18] Radulescu, et al. (2014) Determination of Heavy Metal Levels in Water and Therapeutic Mud by Atomic Absorption Spectrometry. Romanian Journal of Physics, 59, 1057-1066.

[19] Baysal, A., Ozbek, N. and Akman, S. (2013) Determination of Trace Metals in Wastewater and Their Removal Processes. INTECH, London. https://doi.org/10.5772/52025

[20] Barin, J.S., Bartz, F.R., Dressler, V.L., Paniz, J.N.G. and Flores, É.M.M. (2008) Microwave-Induced Combustion Coupled to Flame Furnace Atomic Absorption Spectrometry for Determination of Cadmium and Lead in Botanical Samples. Analytical Chemistry, 80, 9369-9374. https://doi.org/10.1021/ac8015714

[21] US EPA (2000) Environmental Assessment for the Final Effluent Limitations Guidelines, Pretreatment Standards for New and Existing Sources and New Source Performance Standards for the Centralized Waste Treatment Point Source Category. 1-86.

[22] Morrison, G., Fatoki, O.S., Linder, S. and Lundehn, C. (2004) Determination of Heavy Metal Concentrations and Metal Fingerprints of Sewage Sludge from Eastern Cape Province, South Africa by Inductively Coupled Plasma-Mass Spectrometry (ICP-MS) and Laser Ablation-Inductively Coupled Plasma-Mass Spectrometry (LA-ICP). Water, Air, \& Soil Pollution, 152, 111-112. https://doi.org/10.1023/B:WATE.0000015353.16815.b9

[23] Shamuyarira, K.K. and Gumbo, J.R. (2014) Assessment of Heavy Metals in Municipal Sewage Sludge: A Case Study of Limpopo Province, South Africa. International Journal of Environmental Research and Public Health, 11, 2569-2579.

https://doi.org/10.3390/ijerph110302569 
[24] Snyman, H. and Herselman, J. (2006) Guidelines for the Utilisation and Disposal of Wastewater Sludge: Volume 2: Requirements for the Agricultural Use of Wastewater Sludge.

[25] UNEP (2011) Partnership for Clean Fuels and Vehicles; Outcome and Influence Evaluation of the UNEP Based Partnership for Clean Fuels and Vehicles (PCFV). Nairobi.

[26] Mann, R.M., Vijver, M.G. and Peijnenburg, W.J.G.M. (2011) Metals and Metalloids in Terrestrial Systems: Biomagnification and Subsequent Adverse Effects. In: Ecological Impacts of Toxic Chemicals, Bentham Science Publishers Ltd., Sharjah, 43-62. https://doi.org/10.2174/978160805121210043 